\title{
MENGEMBANGKAN MUTU ALAT EVALUASI BELAJAR JENIS MULTIPLE CHOICE MELALUI PEMANFAATAN ICT
}

\author{
Mufliq $^{1}$, Jeffry Handhika ${ }^{2}$, Erawan Kurniadi ${ }^{2}$ \\ ${ }^{1}$ Program Studi Pendidikan Fisika, FPMIPA, IKIP PGRI Madiun \\ ${ }^{2}$ Program Studi Pendidikan Fisika, FPMIPA, IKIP PGRI Madiun
}

\begin{abstract}
ABSTRAK
Pemanfaatan ICT saat ini belumlah optimal. ICT hanya dimanfaatkan sebatas word proses atau yang lebih jauh dimanfaatkan sebagai media pembelajaran. Agar pemanfaatan ICT dapat lebih luas maka dikembangkanlah sebuah alat evaluasi Multiple Choice melalui pemanfaatan ICT. Metode yang digunakan dalam penelitian ini adalah metode penelitian pengembangan dengan model ADDIE. Berdasarkan kelayakan dan kesempurnaan alat evaluasi yang dikembangkan, produk ICT yang dimanfaatkan adalah software Makromedia Flash dan Wondershare QuizCreator.

Instrumen penelitian yang digunakan adalah angket kualitas produk yang di isi oleh mahasiswa, Pakar ICT, dan Observer. Data angket hasil penelitian dari mahasiswa menunjukkan nilai keberhasilan sebesar 77, dari pakar ICT menunjukkan nilai keberhasilan sebesar 76 dan dari Observer menunjukkan nilai keberhasilan sebesar 84.

Berdasarkan analisis data yang dilakukan dapat disimpulkan bahwa soal multiple choice yang dikembangkan dengan memanfaatkan ICT memenuhi standart mutu alat evaluasi. Hal ini terbukti melalui tingginya skor isian angket yang diisi pada uji pakar dan uji coba produk oleh mahasiswa.
\end{abstract}

Kata Kunci: Alat Evaluasi, ICT, Multiple Choice

\section{PENDAHULUAN}

Dunia pendidikan saat ini telah menunjukan kemajuan yang sangat pesat seiring dengan perkembangan Information Comunication and Technology (ICT). ICT mempunyai pengertian yang sama dengan istilah Teknologi Informasi dan Komunikasi (TIK) dalam Munir, (2008:17). ICT adalah Teknologi modern yang mampu menyampaikan informasi melalui piranti komputer. Perkembangan tersebut menuntut adanya usaha persiapan peserta didik agar dapat turut serta dalam upaya pengembangan Information Comunication and Technology bagi generasi berikutnya. Kemampuan untuk memanfaatkan teknologi dalam upaya perkembangan pendidikan tentu sangat tergantung pada jumlah dan kemampuan para ahli dalam bidang pendidikan.

Pemanfaatan ICT saat ini sudah berjalan, namun belum optimal. Saat ini ICT hanya dimanfaatkan sebatas word proses atau yang lebih jauh dimanfaatkan sebagai media pembelajaran. Seharusnya pemanfaatan ICT tidak hanya mencakup 2 hal itu saja. Banyak produk yang dapat di manfaatkan dari ICT sebagai alat bantu dalam dunia pendidikan, misalnya pengembangan mutu alat evaluasi belajar.

Evaluasi merupakan suatu tindakan yang dilakukan oleh evaluator terhadap suatu peristiwa atau kejadian. Alat yang digunakan sebagai sarana untuk menentukan nilai adalah tes. Tes pada umumnya digunakan untuk menilai dan mengukur hasil belajar siswa, terutama hasil belajar kognitif berkenaan dengan penguasaan bahan 
pengajaran sesuai dengan pendidikan dan pembelajaran saat itu.

Tes sebagai alat evaluasi dalam pendidikan mempunyai peranan yang sangat penting dalam mengukur prestasi hasil belajar siswa. Namun jenis tes yang saat ini digunakan masih menggunakan sistem konvensional. Peserta didik menulis jawaban pada kertas yang disediakan penguji. Banyak kelemahan yang ditimbulkan pada sistem ini, misalnya: sistem mencontek yang masih leluasa, waktu pengerjaan yang tidak sesuai dengan rencana awal, lamanya waktu pengkoreksian, kesalahan teknis dalam pengkoreksian, dan human error lainnya. Keadaan tersebut menjadi permasalahan yang mendorong peneliti untuk mengembangkan alat evaluasi baru yang lebih bermutu.

Pengembangan mutu alat evaluasi belajar yang memanfaatkan ICT dirasa mampu menekan kelemahan sistem konvensional yang ada saat ini. Produk alat evaluasi yang dikembangkan ini adalah sebuah barang jadi dalam bentuk software yang dapat dimanfaatkan sebagai alat pengganti dari evaluasi konvensional. Banyak kelebihan yang mampu di berikan oleh produk ini, diantaranya: lebih efisien, meminimalisir human error, mengurangi mencontek, alokasi waktu pengerjaan dapat di desain sebelumnya, dan hasil evaluasi yang langsung bisa dilihat. Alat evaluasi yang dikembangkan ini adalah sebuah produk ICT yang menjawab kelemahan sistem konvensional yang ada saat ini.

Alur pikir peneliti untuk memecahkan masalah yang ditemukan berdasarkan latar belakang dapat di sampaikan melalui bagan berikut:

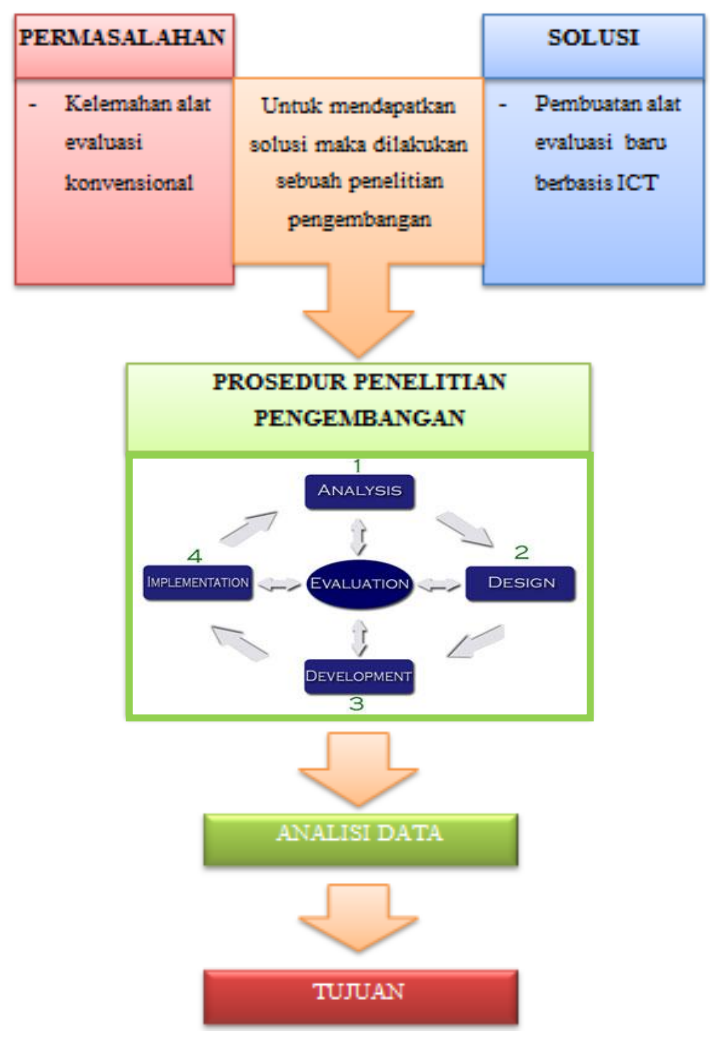

Gambar 1. Alur pikir penelitian

Produk ICT yang dibuat memanfaatkan software Makromedia Flash dan
Wondershare QuizCreator. Macromedia Flash Profesional 8 adalah sebuah program 
animasi yang telah banyak digunakan oleh Animator untuk menghasilkan animasi yang profesional. Diantara program-program animasi, program Macromedia Flash Profesional 8 merupakan program yang paling fleksibel dalam pembuatan animasi, seperti Animasi Interaktif, Game, Company Profile, Presentasi, Movie, dan tampilan animasi lainnya (dalam Madcoms. 2006: 34). Wondershare QuizCreator adalah software yang dapat membantu dan mempermudah pengguna IT dalam membuat kuis atau soal dalam bentuk essai, multiple choice dan lain-lain dengan mudah dan cepat. Nantinya hasil dari kuis atau soal yang dibuat dapat disimpan dengan format doc dan flash (swf) yang bisa dishare dengan pihak lain via e-mail atau diupload di intenet.

Berdasarkan keunggulan program tersebut maka dapat di mungkinkan alat evaluasi yang di hasilkan dari program tersebut mampu memenuhi krieria interaktif, menarik dan menantang. Yang pada akhirnya akan mengembangkan mutu alat evaluasi sendiri.

\section{METODE}

Penelitian dilaksanakan di Kampus IKIP PGRI Madiun. Subjek penelitian adalah mahasiswa fisika semester 6 yang dipillih secara random dengan jumlah 25 mahasiswa, Pakar ICT, dan Observer. Penelitian ini dilakukan menggunakan pendekatan kualitatif yaitu pendekatan yang menghasilkan data deskriptif berupa katakata tertulis maupun lisan dari orang-orang dan perilaku yang diamati (Iyan Afriani H.S, 2009: 1).

Metode yang digunakan dalam penelitian ini adalah metode penelitian pengembangan yaitu penelitian yang bertujuan menghasilkan atau mengembangkan suatu produk berupa model, desain, prototipe, bahan, media, alat atau strategi pembelajaran, guna peningkatan kualitas pembelajaran. Penelitian pengembangan bukan untuk menguji teori, tetapi mengembangkan dan menguji keefektifan model.

Pelaksanaan penelitian menggunakan model konseptual yaitu model yang bersifat analitis menyebutkan komponen-komponen produk, menganalisis komponen secara rinci dan menunjukkan hubungan antar komponen yang akan dikembangkan. Secara lebih khusus pengembangan ini menggunakan model ADDIE. Salah satu fungsinya ADDIE yaitu menjadi pedoman dalam membangun perangkat dan infrastruktur program pelatihan yang efektif, dinamis dan mendukung kinerja pelatihan itu sendiri.

Model ini menggunakan 5 tahap pengembangan yakni :

1. Analysis (analisa)

2. Design (disain / perancangan)

3. Development (pengembangan)

4. Implementation (implementasi/eksekusi)

5. Evaluation (evaluasi/umpan balik)

Data Penelitian yang diambil dari penelitian ini adalah hasil angket kualitas produk yang disebarkan kepada mahasiswa, Observer dan Pakar ICT. Sebelum melaksanakan pengambilan data perlu dipersiapkan dulu instrumen yang akan digunakan. Instrumen yang digunakan ada dua buah, yaitu: Produk yang diujicobakan dan lembar angket kualitas produk.

Teknik analisis yang digunakan adalah teknik analisis data kualitatif dilakukan dengan menelaah seluruh data, mereduksi data, membuat kategorisasi, menafsirkan data, dan memberikan pemaksaan hasil (gambar 2).

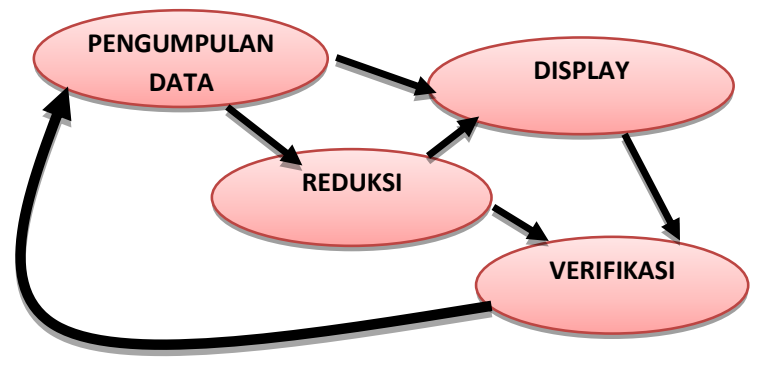

Gambar 2. Tahap Analisis Data Kualitatif Sumber: Bambang Budi Wiyono (2009: 40) 
Penelitian ini akan dikatakan berh ${ }^{-1}$ jika target indikator keberhasilan penelit ini tercapai. Indikator Keberhasilan

Penelitian disajikan pada tabel 1.1 berikut:

Tabel 1.1 Indikator Keberhasilan Penelitian

\begin{tabular}{clcc}
\hline No & \multicolumn{1}{c}{ Indikator } & $\begin{array}{c}\text { Target } \\
\text { Pencapaian }\end{array}$ & Cara menghitung \\
\hline 1. & $\begin{array}{l}\text { Mutu alat evaluasi } \\
\text { dari Mahasiswa }\end{array}$ & 70 & Nilai Kualitas $=\frac{\sum \text { Nilai Semua mahasiswa }}{\sum \text { mahasiswa }}$ \\
\hline 2. & $\begin{array}{l}\text { Mutu alat evaluasi } \\
\text { dari Observer }\end{array}$ & 70 & Nilai Kualitas $=\frac{\sum \text { Nilai Semua observer }}{\sum \text { observer }}$ \\
\hline 3. & $\begin{array}{l}\text { Mutu alat evaluasi } \\
\text { dari Pakar }\end{array}$ & 70 & Nilai Kualitas $=\frac{\sum \text { Nilai Semua pakar }}{\sum \text { pakar }}$ \\
\hline
\end{tabular}

Keterangan:

Target pencapaian angket uji coba produk dari Mahasiswa, Observer, dan Pakar adalah 70. Penentuan target pencapaian ini melalui prediksi berdasarkan lembar observasi kualitas produk yang digunakan dan kelayakan.

\section{HASIL DAN PEMBAHASAN}

Prosedur yang dilakukan dalam penelitian pengembangan ini telah mengikuti model ADDIE yang hasilnya adalah sebagai berikut:

a. Analysis: Berdasarkan analisis kebutuhan dihasilkan spesifikasi instrumen dan berdasarkan analisis mater dihasilkan kumpulan soal fisika yang sesuai dengan materi yang dipelajari. Soal-soal yang terkumpul sudah melewati proses validasi dan reabilitas.

b. Design: Pada langkah ini direncanakan bagaimana soal yang telah diperoleh pada tahap analisis dimasukkan dalam bentuk ICT. Mulai dari tata letak, pilihan jawaban, simulasi, instruksi dan penilaian yang akan dikeluarkan. c. Development: Pada langkah ini merealisasikan hasil dari desain sehingga memperoleh produk yang nyata dan dapat digunakan.

d. Implementation: Pada langkah ini produk yang dihasilkan dari development mulai diujicobakan pada objek ujicoba (pengambilan data).

e. Evaluation: Pada langkah ini dilihat apakah alat evaluasi yang dibuat dan diujicobakan telah sesuai dengan harapan awal pembuatan melalui analisis data yang dilakukan.

Data yang didapat pada penelitian ini terangkum dalam tiga aspek, tampilan dan analisis datanya adalah sebagai berikut.

\begin{tabular}{clccc}
\hline NO & \multicolumn{1}{c}{ Indikator } & $\begin{array}{l}\text { Skor Total } \\
\text { Perolehan }\end{array}$ & Skor Target & Keterangan \\
\hline 1 & $\begin{array}{l}\text { Mutu Kualitas Produk berdasarkan } \\
\text { isian anket dari Siswa }\end{array}$ & 77 & 70 & bermutu \\
\hline 2 & $\begin{array}{l}\text { Mutu Kualitas Produk berdasarkan } \\
\text { isian anket dari Observer }\end{array}$ & 84 & 70 & bermutu \\
\hline 3 & $\begin{array}{l}\text { Mutu Kualitas Produk berdasarkan } \\
\text { isian anket dari Pakar }\end{array}$ & 76 & 70 & bermutu \\
\hline
\end{tabular}


Dari tabel di atas dapat disimpulkan bahwa produk yang dibuat penelitian ini telah berhasil melampaui target. Jadi mutu alat evaluasi sudah berkembang sesuai tujuan penelitian.

\section{KESIMPULAN}

Berdasarkan hasil penelitian dan pembahasan dalam penelitian ini dapat disimpulkan bahwa:

Soal multiple choice yang dikembangkan dengan memanfaatkan ICT memenuhi standart mutu alat evaluasi. Hal ini terbukti melalui tingginya skor isian angket yang diisi pada uji pakar dan uji coba produk oleh mahasiswa.

\section{SARAN}

a. Dalam pembuatan alat evaluasi berbasis ICT peneliti dapat menggabungkan dari beberapa aplikasi sekaligus, sehingga dapat menghasilkan alat evaluasi yang menarik dan bermutu.

b. Penggunaan alat evaluasi berbasis ICT lebih efisien jika digunakan pada kelas yang dilengkapi dengan komputer terkoneksi dalam sebuah jaringan LAN.

c. Penilaian hasil perlu di lengkapi dengan fasilitas on-line agar lebih cepat.

\section{DAFTAR PUSTAKA}

Abdul Hakim. 2013. Pengembangan Pembelajaran Termodinamika Berbasis ICT, (online), (http://www.jurnal.upi.edu/file/UASArtikel_Abdul_Hakim_1104512.doc x, Diunduh 07 Februari 2013).

Asep Wahyu Nugroho. 2009. Peningkatan Kompetensi Dan Minat Mahasiswa Terhadap Matakuliah Dasar Kimia Kuantum Melalui Pemakaian Media Pembelajaran Berbasis IT/ICT. Jurnal Pendidikan Matematika Dan Sains, 4 (2): 82-88.

Badarudin. 2011. Model Pengembangan Perangkat Pembelajaran, (online), (http://ayahalby.wordpress.com/2011 /02/23/model-pengembanganperangkat-pembelajaran/, Diunduh 5 Juni 2012).

Bambang Budi Wiyono. 2009. Penelitian Tindakan Kelas dan Penulisan Karya Ilmiah. Malang: Universitas Negeri Malang.

Benny A Pribadi. 2010. Model Desainsistem pembelajaran. Jakarta: Dian Rakyat.

Deni Darmawan. 2011. Teknologi Pembelajaran. Bandung: PT. Remaja Rosdakarya.

Isjoni dan Firdaus LN. (Eds.). 2008. Pembelajaran Terkini: Perpaduan Indonesia-Malaysia. Yogyakarta: Pustaka Pelajar.

Iyan Afriyani. 2009. Metode Penelitian Kualitatif, (online), (http://www.penalaranunm.org/index.php/artikelnalar/penelitian/116-metodepenelitian-kualitatif.html, Diunduh 18 Februari 2012).

Madcoms. 2006. Macromedia Flash Pro 8. Yogyakarta: CV. Andi Offset.

Munir. 2008. Kurikulum Berbasis Teknologi Informasi Dan Komunikasi. Bandung: CV. Alfabeta.

Ngalim Purwanto. 2010. Prinsip-Prinsip dan Teknik Evaluasi Pembelajaran. Bandung: PT. Remaja Rosdakarya.

Sugiyono. 2011. Metode Penelitian Pendidikan Pendekatan Kuantitatif, Kualitatif, dan R \& D. Bandung: Alfabeda.

Supardiyono. 2009. Pengembangan Media Pembelajaran Interaktif Dengan Aplikasi Program Microsoft Office Power Point Pada Materi Tata Surya, Jurnal Pendidikan Matematika dan Sains (online), Jilid 16, no. 1 (http://pmipa.jurnal.unesa.ac.id/34_2 27/pengembangan-mediapembelajaran-interaktif-denganaplikasi-program-microsoft-office- 
power-point-pada-materi-tata-surya, Diunduh 13 Juni 2012).
Zainal Arifin. 2011. Evaluasi Pembelajaran.

Bandung: PT. Remaja

Rosdakarya 